\title{
EDITORIAL
}

\section{A new path for Human Cell}

\author{
Hiroaki Kataoka
}

Published online: 28 February 2013

(C) Japan Human Cell Society and Springer Japan 2013

Last year marked the 30th anniversary since the Japan Human Cell Society (JHCS) was launched and the 25th anniversary for Human Cell, the official journal of this exceptional society. I am highly honored to be named the new Editor-in-Chief of Human Cell in this year at the beginning of a new quarter-century for the journal and it is my intention to further enhance the quality and recognition of the journal.

JHCS was initially established in 1983 under the name "Human Cell Research Meeting" for comprehensive presentation of research findings using cultured cells particularly of human origin, and for exchange of opinions by researchers in various fields. As cell lines derived from human organs and tissues became a crucial component of rapidly expanding fields of biomedical research, the society sought for a platform to publish cell line derivation and studies on subjects related to cultured human cells. Then, the official journal of this society was first published in 1988 under the title Human Cell. Since then, the journal has covered studies using human cells and embryonic stem cells derived from animals, regenerative medicine using animal cells, and reports for cell line establishment and derivation. My editorial predecessors have served the journal very well and I thank former Editor-in-Chief Dr. Isamu Ishiwata for his assistance during the recent editorial transition. Dr. Ishiwata's efforts to broaden the scope of Human Cell to include important translational study for regenerative medicine and to expand the distribution of Human Cell raised the awareness of the journal in the international science community.

The purpose of JHCS is to promote the scientific knowledge and clinical application of basic research using human cells and embryonic stem cells derived from animals or regenerative medicine using animal cells. Human Cell should meet JHCS's publication goals. However, at the same time, the journal should achieve an impact that attracts higher quality submissions from a variety of research fields. It is my objective as incoming Editor-inChief to ensure this result. Human Cell is a peer-reviewed journal that will serve as a forum for international research on all aspects of human cell biology, embryonic stem cells derived from animals, regenerative medicine, and the cellular and molecular biology of diseases including neoplasia. I humbly look forward to working with Human Cell contributors, JHCS members, and the broader scientific community to enhance the scientific impact of Human Cell.

H. Kataoka ( $\square)$

Miyazaki, Japan

e-mail: mejina@med.miyazaki-u.ac.jp 